Meta

Journal des traducteurs

Translators' Journal

\title{
Semantic Mapping of a Text (Exodus 23,8): A Descriptive Approach to Translation Equivalence
}

\section{Aryeh Newman}

Volume 23, numéro 2, juin 1978

URI : https://id.erudit.org/iderudit/003727ar

DOI : https://doi.org/10.7202/003727ar

Aller au sommaire du numéro

Éditeur(s)

Les Presses de l'Université de Montréal

ISSN

0026-0452 (imprimé)

1492-1421 (numérique)

Découvrir la revue

Citer cet article

Newman, A. (1978). Semantic Mapping of a Text (Exodus 23,8): A Descriptive

Approach to Translation Equivalence. Meta, 23(2), 127-131.

https://doi.org/10.7202/003727ar d'utilisation que vous pouvez consulter en ligne. 


\section{Semantic Mapping of a Text (Exodus 23,8) A Descriptive Approach to Translation Equivalence*}

From a broad linguistic descriptive point of view, the meaning options supported by a text, irrespective of their motivation are all equally valid, as are all usages in language practised and accepted by narrative speakers. Some motivations may, however, not carry conviction in certain circles, just as certain registers are contra-indicated in some situations.

The translator should be aware of these options, making his own deliberate choice in accordance with the demands of his own translation. Accuracy and readability are terms relative to the aims and purposes of the particular version which are conditioned by considerations of time, place, audience and various other factors that characterize the total situation enveloping the act of translation. Modern translation theory (Catford, 1965 ; Nida, 1964) attempts to outline a model of the tasks facing the translator at the various levels of language : phonological, syntactic and semantic. The latter are neither mutually exclusive nor exhaustive. Stylistic and pragmatic issues are involved at all these levels. We shall concern ourselves with the semantic, aware, however, that it cannot be isolated from the other aspects of language referred to. But it is a useful and central starting point for tackling problems of translation equivalence.

In the case of Bible translation, from which our example is taken (similar examples could be adduced from literary texts of ancient and modern vintage), the configuration of the text and the meaning are not always easily determined. Sometimes the text is indeterminate, sometimes obscure, and at others, perhaps deliberately ambiguous. The various explications of the text may be traced to the variety of meanings sustained by the text. A descriptive approach confines itself to the mapping of these options. The translator has to decide either (1) that it is both a desirable and feasible task to reproduce them, in which case he will have indicated that he regards the ambiguity of the text as functional (cf. Catford, 1965 : 94 ; Newman, 1975) or (2) choose the particular reading

\footnotetext{
This paper is based on a Hebrew version delivered at the Third Annual Conference of the
} Israel Association of Applied Linguistics (IAAL), held at Tel Aviv University, July 1976. 
he regards as the meaning of the original, which is the normal procedure ${ }^{1}$. Whichever procedure he adopts, the translator will be guided by readings extant in previous translations and exegeses provided they are prompted by the actual configuration of the text ${ }^{2}$. A knowledge of these «performances 》 will provide further reinforcement for the translator's « competence $\gg$ based on the expectancies created by the tradition he has already mastered (cf. Newman, 1978).

The process of capturing the meaning potentialities of the source text proceeds in two directions : from the various translations and explications to the text, or vice versa : from the text, or rather the individual reading of it, to the various interpretations. In practice, the explicator of a text works in both directions at once. His general understanding of a text and specific sensitivity to its anomalies are the fruits of his previous experience, constantly enriched and monitored by his consultation of the comments made by serious readers and scholars. The anomalies are discovered by reference to stylistic ${ }^{3}$ and linguistic norms, which themselves have been extracted from generations of encounters with the text and are reflected, in the case of ancient records, in the comment of millenia. This comment and study embraces extra-textual activity such as archaelogy and the findings of other sciences.

Now to our text. I have deliberately taken a familiar and what might be taken as a relatively straightforward text, Exodus 23,8, which records the prohibition of taking bribes «because they blind the eyes of the clearsighted ». Then come three Hebrew words :

\section{/ viysallef / divrei / tzaddiqim}

The KJB's rendering of these words is :

/ and-perverteth / the-words-of / the-righteous.

Commentaries from the earliest times have been in dispute over the reading of this clause, a situation reflected in the various translations, which have reproduced one or more of the interpretative potentialities of the source text.

The first ambiguity arises from the uncertain implications of the syntactic combination exemplified by the last two words, often referred to as the construct. Which of the two Hebrew nominals (divrei or tzaddiqim) is attributive? We have no way in English of reproducing this ambiguity of the Hebrew construct in this context. The translator has to choose between (a) and (b) :

words of (a) $\leftarrow$ righteousness (righteous words)

(b) $\rightarrow$ the righteous

1. Cf : preface to the NEB : « Each member brought his view about the meaning of the original to the judgment of his fellows - discussions went on till they reached a common mind... alternative meanings have been recorded in footnotes, but only where they seemed of sufficient importance.

2. Cf : Hirsch (1968:99) who suggests that the best guard against over-subjectivity and distortions is \& to take everything into account... find a place in a system of meaning for every detail $\gg$.

3. Cf : Enkvist $(1973: 146)$ : " The construction of stylemarkers based on stylistic probabilities determined by the context and past experience of contextual frequencies. 
The arrow represents the direction of the attribution. Alternatively, we may represent the semantic choice opened up by the ambiguity of the syntactic construction. as follows :

$$
\text { Integrity (I) } \quad\left\{\begin{array}{l}
\rightarrow \text { words }(-\mathrm{H}) \\
\rightarrow \text { persons }(+\mathrm{H})
\end{array}\right.
$$

There is a quality or state of integrity (righteousness, uprightness, justice, etc.) which may be applied to persons (tzaddiqim) « righteous (persons) 》 or words (divrei-tzaddiqim). The human focus $(+\mathrm{H})$ of the modifier which is part of the meaning of the Hebrew nominal tzaddiqim as in the English « righteous » gives us reading (b). The non-human $(-\mathrm{H})$ focus of the modifier (I) spelt out in «words-of » gives us reading (a).

The more ancient versions - Septuagint, Targum Onkelos followed later by Rashi adopt reading (a). Reading (b) followed by the KJB is found in the Vulgate and supported by Ibn Ezra and the majority of medieval and modern commentators ${ }^{4}$.

The second source of ambiguity is of greater concern to the translator having very well-defined semantic repercussions. Who are «the righteous»? Are they «the righteous » by virtue of their judicial or legislative office, their personal conduct, or the nature of their cause? Is it the judge or any person in a position of trust whose behaviour is perverted by the bribe or simply the innocent party's case ? Or in reading (a) are «the righteous words 》 (« words of righteousness $\gg$ ) those of the judge (his verdict), the innocent party (their pleas) or the Lawgiver or legislator whose laws are perverted? None of these possible readings are mutually exclusive since the effect of any perversion in the process of justice cannot be confined to any particular aspect but affects all the elements in the situation : the judge (or any person involved in determining the truth), the parties and the law. The idea of focus is here rewarding. There are three foci to the context of the Biblical dictum : the judicial (not necessarily professional) role $(J)$, the parties $(\mathrm{P})$ and the law $(\mathrm{L})$; divreitzaddiqim encapsulates them all. We can now extend our semantic mapping to capture the interpretative potentialities of the phrase divrei-tzaddiqim :

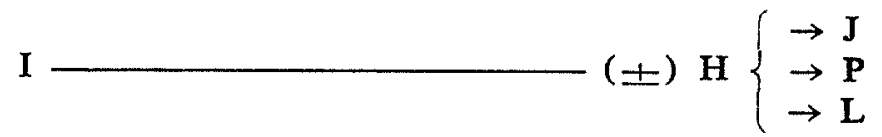

Here is a sample of English and French Bible translations of this text systematized according to foci $(\mathrm{J}),(\mathrm{P})$ and $(\mathrm{L})$ and syntactic focus on person or object $( \pm \mathrm{H})$. The translations themselves are grouped according to the combination of features they share.

The KJB 1(a) characteristically strives to preserve the general syntactic structure of the ST. Of the two possible syntactic readings of divrei tzaddiqim it reproduces, unlike the Septuagint (4), the one in which divrei is subordinate

4. A full survey of Jewish explications of the text will be found in Leibowitz (1976:453-456). For the ambiguity problem faced by the translator, see translator's note op. cit. 456-457. 


\begin{tabular}{|l|l|l|l|l|}
\hline 1. (a) perverteth the words of the righteous (KJB) & J & P & L & H \\
(b) pervertit les paroles des justes (Dhorme) & $\times$ & $\times$ & $\times$ & + \\
\hline 2. (a) destroys the case of a good man (Moffat) & \\
(b) subverts the cause of those who are in the right (RSV) \\
(c) and is the ruin of the just man's cause (JrB) \\
(d) ruine les causes de ceux qui sont dans le droit (Clamer) \\
(e) perdent les causes des justes (VS) \\
(f) upsets the pleas of the just (NJB) & & \\
\hline 3. (a) disturbs the judgement even of the just men (Knox) & & \\
(b) makes the just men give a crooked answer (NEB) & & \\
\hline 4. corrupts just words (S) & & \\
\hline 5. ruine les causes justes (BJ) & & \\
\hline
\end{tabular}

to tzaddiqim. But this hardly narrows the interpretative potentialities of the text. The * words of the righteous » can be those of the judge, the innocent party or the legislator. The same transfer of the triple focus of the ST is achieved by the, admittedly, stylistically infelicitous «corrupts just words » of (4). The « just words » may be those of the judge, the parties, the lawgiver or legislator. Both select unmarked lexemes which is a characteristic of the ST. Divrei is almost a dummy word. "Words » is less so, but is unmistakably unmarked when compared with the terms : «cause», «case » and «laws» found in other versions. Similarly, « righteous», « just», « justes» are unmarked terms in contrast to the definitive : «those who are in the right». The more recent translations sound more felicitous to the modern reader because they reflect a contemporary register. But the result is to narrow the meaning range of the text. 2(a)-(f) focus on the innocent party to a dispute; 3(a)-(b) stress the judicial role. All, with the exception of the NEB 3(b), adhere to the syntactic form of the original.

The final evaluation of the end-product will depend on the criteria adopted by both translator and readers. There is no linguistic consensus on the definition of translational equivalence. Catford stresses interchangeability in the same situation. Generativists focus on a common deep structure. What criteria should we select for determining equivalence? My semantic mapping focuses on the dimension of interpretative potentialities. There can be no uniform answer. Literary, «luminous» texts call for a greater attention to the range of interpretation. Their ambiguity is often functional and translatable, as is demonstrated here. It is not to be confused with the comparatively trivial and restricted type of ambiguity found in puns and word-plays. The kind of semantic mapping illustrated here forms an essential part of the process of striving for translational equivalence, irrespective of the final criteria adopted by the translator. The latter must make an informed choice, be as aware of the option he has rejected as of the one he has selected.

ARYeH NewMan 


\section{REFERENCES}

BJ., la Bible de Jérusalem, Paris, Éditions du Cerf, 1973.

CATFORD, J.C.. A Linguistic Theory of Translation, London, Oxford University Press, 1965.

CLAMER, A., la Sainte Bible, Paris, 1956.

DHORME, E., la Bible, La Librairie Gallimard, 1956.

ENK.VIST, N.E., Linguistic Stylistics, The Hague, Mouton, 1973.

HIR SCH, Jr. S.D., «Literary Valuation as Knowledge», in : Dembo L.S. (ed.) Criticism, London, University of Wisconsin Press, 1968.

JrB., The Jerusalem Bible, Alexander Jones, London, Chapman, 1971.

KJB., King James Bible.

KNOX, R.A., The Holy Bible, London, Burns and Oates, 1955.

LEIBOWITZ, N., Studies in Shemot - the Book of Exodus - in the context of ancient and modern Jewish Bible Commentary, translated by A. Newman, Jerusalem, World Zionist Organization, 1976.

MOFFAT, J., A New Translation of the Bible, London, Hodder \& Stoughton, 1925.

NEB., The New English Bible, Cambridge, Oxford University Press, Cambridge University Press, 1970.

NEWMAN, A., «Componential analysis and functional ambiguity equivalence : translating Exodus 32, 17-18 », Babel 21, 29-35, 1975.

NEWMAN, A., "Genesis 2,2 : An exercise in interpretative competence and performance ", Technical Papers for the Bible Translator, 27. 101-104, 1976.

NEWMAN, A., "Close reading and open semantic models》, in : Proceedings of the XIIth International Congress of Linguists, Vienna, 1977, Innsbruck, Institut für Sprachwissenschaft der Universität Innsbruck (forthcoming), 1978.

NIDA, E.C., Towards a Science of Translating, Leiden, Brill, 1964.

NJB., New Jewish Bible, The Torah, Philadelphia, The Jewish Publication Society of America, 1962.

S., The Septuagint Version of the Old Testament, London, Bagster.

VS., Version Synodale, la Sainte Bible, Lausanne, 1956. 